\title{
FILSAFAT PERENIAL SEBAGAI ALTERNATIF METODE RESOLUSI KONFLIK AGAMA DI INDONESIA
}

\author{
M. Baharudin \\ Institut Agama Islam Negeri (IAIN)Raden Intan Lampung \\ e-mail: beryyunianto@yahoo.com
}

\begin{abstract}
The article aims to offer the perennial philosophy can be used as an alternative method of resolving a conflict of religion in Indonesia. For this purpose the perennial philosophy offers several approaches were: a.) Offering a dialogue method, perennial philosophy offers a method of inter-religious dialogue, the method of phenomenology (phenomenology of religion). This method is a way of understanding the appreciative attitude without the attitude of conquest and accused infidels other faiths. This method avoids the external attitude that considers religion of others is definitely wrong and only the one true religion. Then the ethics of dialogue is not intended to interfere in the affairs and other religious teachings, nor to make others fall into his faith, but to deepen their own faith traditioncritically. b.) the inevitability of their commitment to religious plurality. Perennial philosophy in the context of religious plurality believes that inview of this religious plurality perennial philosophy seeks to find common plat forms or common vision in tracing the chain of the historicity of religious growth, searching for the essence of the plurality exotericesoteric in each of the religions. Perennial philosophy in view of religious pluralism believe that every religionis derived from the same source, namely from the Absolute, the truth comes from the One.
\end{abstract}

Abstrak: Artikel ini bertujuan untuk menawarkan filsafat perennial dapat dijadikan sebagai alternatif metode resolusi koflik agama di Indonesia. Untuk maksud tersebut filsafat perennial menawarkan beberapa pendekatan antara lain yaitu: a.)Menawarkan metode dialog, filsafat perennial menawarkan suatu metode dialog antar umat beragama, yaitu metode fenomenologi (fenomenologi agama). Metode ini merupakan cara memahami dengan sikap apresiatif tanpa sikap penaklukan dan pengkafiran penganut agama lain. 
M. BAHARUDDIN:Filsafat Perenial...

Metode ini menghindari sikap eksternal yang menganggap agama orang lain pasti salah dan hanya agamanyalah yang benar. Maka secara etik dialog tidak dimaksudkan untuk mencampuri urusan dan ajaran agama lain, juga tidak untuk menjadikan orang lain masuk dalam keyakinan yang dianutnya melainkan untuk memperdalam tradisi agama sendiri-sendiri secara kritis.b.)Komitmen keniscayaan adanya pluralitas dalam agama. Filsafat perennial dalam konteks pluralitas agama meyakini bahwa dalam melihat pluralitas agama ini filsafat perennial berusaha mencari titik temu (Common Platfom atau Common Vision) dalam menelusuri matarantai historisitas tentang pertumbuhan agama, mencari esensi esoteris dari pluralitas eksoteris pada masing-masing pada agama yang ada. Filsafat perennial dalam melihat pluralism agama meyakini bahwa setiap agama berasal dari sumber yang sama yaitu dari Yang Mutlak, kebenaran berasal dari Yang Satu.

Keywords: Filsafat Perennial, Resolusi Konflik, Indonesia, dialog, pluralitas.

\section{A. Pendahuluan}

Indonesia adalah suatu Negara yang berpenduduk yang plural terdiri dari berbagai suku, agama, adat istiadat dan budaya dapat hidup berdampingan danmemiliki ruang negosiasi yang sangat tinggi dalam kehidupan sehari-hari. ${ }^{1}$ Di samping itu penduduknya di kenal religius, santun dan ramah-tamah. Namun itu semua telah dinodai oleh sejarah lembaran-lembaran hitam. Noda-noda itu ialah telah terjadi konflik sosial antara lain yang bernuansa agama diberbagai wilayah Indonesia yang mempunyai falsafah hidup Pancasila. Konflik sosial yang menjurus kerusuhan dan kekerasan itu telah menelan tidak sedikit korban jiwa dan harta.

Konflik-konflik sosial yang bernuansa agama yang mengarah pada kerusuhan dan kekerasan itu dalam konteks ke-Indonesiaan ini dapat di lacak misalnya dalam kasus konflik sosial bernuansa agama di Ambon, di Poso, di Banjarmasin, di Kupang, dan masih banyak lagi konflik-konflik sosial yang terjadi di Indonesia. ${ }^{2}$ 
M. BAHARUDDIN:Filsafat Perenial...

Bahwa konflik-konflik sosial yang menjurus kerusuhan dan kekerasan yang terjadi di berbagai wilayah Indonesia sebagaimana dipaparkan di atas, adalah disebabkan oleh beberapa faktor antara lain adalah faktor kesenjangan ekonomi, benturan budaya, ketidak adilan dan kemiskinan ketidak pastian hukum, budaya lokal tergusur, faktor politik yang melibatkan simbol-simbol agama, dan pemahaman keagamaan yang tidak benar.

Bertitik tolak dari empirisitas yang memberikan gambaran tentang konflik yang memberikan pengalaman pahit dalam relasinya interaksi antar kelompok dalam kehidupan sosial, maka lahirlah sejumlah teori antara lain memberikan alternatif metode dan pendekatan dalam mengelola dan menyelesaikan konflik. Secara epistemologi berbagai metode dan pendekatan yang ditawarkan, kelahirannya dilatarbelakangi oleh empirisitas dari beberapa kelompok masyarakat dunia dengan masing-masing setting sosialkultural yang berbeda satu dengan yang lain. Karena perbedaan tersebut juga maka sebuah metode yang telah terbukti berhasil diterapkan dalam sebuah komunitas masyarakat kemungkinan akan melahirkan kondisi yang berbeda ketika diterapkan pada komunitas lain dengan setting sosial kultural yang berbeda. ${ }^{3}$ Sehingga cara ideal pendekatan dalam mengelola dan resolusi konflik sejatinya merupakan hasil penelusuran dari nilai budaya di tengah masyarakat terutama dimana konflik tersebut ingin di kelola untuk tidak terjadi atau di selesaikan ketika konflik itu terjadi. ${ }^{4}$

\section{B. Wacana Teoritik Tentang Konflik}

\section{Pengertian Konflik}

Menurut Hasan Shadely konflik berasal dari bahasa Latin "confliction" yang berarti saling berlawanan "atau" saling bertentangan. ${ }^{5}$ Poerwadarminta dalam Kamus Umum Bahasa Indonesia yang disusunannya menjelaskan bahwa konflik berarti "pertentangan atau percekcokan. ${ }^{6}$ Pertentangan ini bisa lahir dalam 
M. BAHARUDDIN:Filsafat Perenial...

bentuk pertentangan ide maupun fisik antara dua belah pihak berseberangan. Diana Francis dalam bukunya Teori Dasar Transformasi Konflik Sosial menambahkan unsur persinggungan dan pergerakan sebagai aspek tindakan sosial".7 Sehingga secara sederhana konflik adalah pertentangan yang ditandai oleh pergerakan beberapa pihak sehingga terjadi persinggungan.

Pengertian konflik di atas menurut Susan sesuai dengan apa yang didefinisikan oleh Bruit dan Rubin dengan mengutip Weber bahwa konflik berarti persepsi mengenai perbedaan kepentingan (Peceived Divergence Interes), atau suatu kepercayaan bahwa aspirasi pihak-pihak yang berkonflik tidak tercapai secara simultan. ${ }^{8}$ Jika memperhatikan konflik pada dimensi diatas maka unsur-unsur yang ada dalam konflik adalah persepsi, aspirasi, dan aktor yang terlibat didalamnya. ${ }^{9}$ artinya dalam dunia sosial yang ditemukan persepsi maka akan di temukan pula aspirasi dan aktor. ${ }^{10}$

Menurut Novri Susan, Konflik bisa lahir pada sekala yang berbeda seperti konflik antar orang (interpersonal conflict) konflik antar kelompok dengan negara (vertical conflict), konflik antar negara (inter state conflict) selanjutnya Novri Susan menjelaskan bahwa setiap konflik memiliki latar belakang dan arah perkembangannya. Masyarakat di dunia pada dasarnya memiliki sejarah konflik dalam sekala antar perorangan sampai negara. ${ }^{11}$

Konflik yang bisa dikelola secara arif dan bijaksana akan mendinamisasi proses dan bersifat konstruktif bagi perubahan sosial masyarakat dan tidak menghadirkan kekerasan. Menurut Novri Susan dalam sejarah masyarakat dunia, konflik sering diikuti oleh bentuk-bentuk kekerasan, seperti perang dan pembantaian. Dalam historisitas kemanusiaan bahwa konflik selalu menjadi bagian tak terpisahkan dari hidup manusia yang bersosial dan berpolitik serta mendorong dalam dinamika dan perubahan sosial politik. ${ }^{12}$ Menurut Novri Susan,istilah konflik membersitkan makna negatif bagi kelompok dan sejarah tertentu sebagaimana Indonesia pada masa 


\section{BAHARUDDIN:Filsafat Perenial...}

Orba. Rezim Orde Baru melihatnya bahwa konflik harus dinegasikan dari dunia sosial politik karena konflik berarti ketidak stabilan, ketidak harmonisan, dan ketidak mapanan. ${ }^{13}$

Rezim Orde Baru mendefinisikan konflik secara sempit dan negatif. Konflik selalu direlasikan dengan ketidakamanan dan ketidak harmonisan. Sesungguhnya realitas ini tidak logis tidak lepas dari tiga hal a) trauma sejarah akibat ketidak stabilan politik pada masa rezim orde lama. b) adalah dominasi ilmu sosial fungsional struktural di dunia keilmuan sosial Indonesia pada periode itu, dan c) adalah kepentingan pembangunanisme yang mensyaratkan stabilitas politik berlebihan. ${ }^{14}$ Historisitas inilah yang selanjutnya mengharamkan konflik dan mengetepikan eksistensi dinamika sosial. Sehingga segala potensi, modal sosial, aspirasi, dan konflik yang terpendam muncul secara radikal dalam bentuk kekerasan selama transisi demokrasi sejak $1998 .{ }^{15}$ Berelasi dengan problemsitas ini secara lebih arif dan mendalam melalui disiplin sosiologi konflik. ${ }^{16}$ Oleh karena itu konflik menjadi unsur terpenting dalam kehidupan manusia karena konflik memiliki fungsi positif. ${ }^{17}$

Simon Fisher membedakan antara konflik dan kekerasan. Menurut Fisher " konflik adalah hubungan antara dua pihak atau lebih (individu atau kelompok yang memiliki atau yang merasa memiliki sasaran-sasaran yang tidak sejalan".18 Kekerasan meliputi tindakan, perkataan, sikap, berbagai struktur atau sistem yang menyebabkan kerusakan secara fisik, mental, sosial atau lingkungan dan atau menghalangi seseorang untuk meraih potensinya secara penuh. ${ }^{19}$

Menurut Fisher konflik adalah suatu realitas hidup tidak terhindarkan dan sering bersifat kreatif. Konflik terjadi ketika tujuan masyarakat tidak sejalan, berbagai perbedaan pendapat dan konflik biasanya diselesaikan tanpa kekerasan, dan sering menghasilkan situasi yang lebih baik bagi sebagian besar atau semua pihak yang terlibat konflik. karena itu konflik tetap berguna. ${ }^{20}$ 
M. BAHARUDDIN:Filsafat Perenial...

Kembali kepada masalah pengertian konflik, Titik Suwaryati dengan mengutip Selo Soemardjan dan Soeleman Soemardi mengatakan bahwa konflik merupakan salah satu bentuk interaksi sosial Bentuk-bentuk interaksi sosial. dapat berupa kerja sama (cooperation) persaingan (competation) dan bahkan dapat berbentuk pertentangan (conflict).21

Menurut Mansur Hidayat, konflik bisa dipakai sebagai suatu "proses sosial" dimana dua orang atau dua kelompok orang berusaha menyingkirkan pihak lain dengan cara menghancurkan atau membuatnya tidak berdaya. ${ }^{22}$ Wujud konflik yang paling nampak adalah perang bersenjata, dimana dua atau lebih bangsa atau suku bangsa saling bertempur dengan tujuan menghancurkan atau membuat pihak lawan tidak berdaya. Pihak-pihak yang terlibat konflik, dikuasai oleh suatu keinginan untuk mencapai suatu hasil yang dipersengketakan. ${ }^{23}$ Fokus perhatian masing-masing terarah pada dua hal ; a) adanya lawan yang menghalangi dan b) adanya nilai lain yang akan di capai. ${ }^{24}$ Dalam historisitas manusia telah mencatat bahwa dalam peperangan yang terjadi pada masa lampau di temukan adanya nilai sebagai motif perjuangan, seperti nilai demokrasi untuk meraih kebebasan persamaan hak, perbaikan nasib kaum buruh, dan ekspansi wilayah atau daerah, nilai keagamaan (perang salib) nilai kemerdekaan dan kedaulatan bangsa.

Sebagaimana dipaparkan di muka, bahwa sebagai pristiwa sosial maupun individu konflik bisa lahir dalam beragam skala; misal konflik antar orang (inter personal conflict), konflik antar kelompok (inte group conflict) konflik antar negara (interstate conflict) setiap sekala memiliki latar belakang dan arah perkembanganya. Komunitas dunia pada dasarnya mempunyai historisitas konflik dalam skala antar perorangan hingga antar negara. Konflik yang di menage secara bijak dan arif akan mendinamisasi proses sosial bersifat konstruktif bagai perubahan sosial dan tidak menjurus kekerasan. 
M. BAHARUDDIN:Filsafat Perenial...

Meskipun konflik dapat memberikan motivasi bagi terjadinya dinamika, namun sisi yang lain bahwa konflik juga memunculkan berbagai kondisi yang negatif, yang paling tidak menjadi kendala bagi dinamika yang lebih progres dan perubahan sosial budaya dalam bentuk lebih produktif bagi tercapainya kesejahteraan bersama dalam bentuknya yang lebih ideal.

\section{Jenis dan tipe-tipe konflik}

Dalam teori sosiologi konflik terdapat beberapa tipologi konflik, misal adanya konflik eksternal, konflik internal-konflik "obyektif lahiriah dan konflik "subyektif-batiniah".

Lowis Coser menjelaskan tentang adanya konflik eksternal dan konflik intenal. Menurut Coser konflik eksternal (eksternal conflict) mampu menciptakan dan memperkuat identitas kelompok konflik membuat batasan-batasan di antara dua kelompok dalam sistem sosial dengan memperkuat kesadaran dan kesadaran kembali atas keterpisahan sehingga menciptakan kesadaran identitas kelompoknya dalam sistem. ${ }^{25}$

Menurut Coser, konflik eksternal akan menjadi proses refleksi kelompok-kelompok identitas mengenai kelompok diluar mereka sehingga meningkatkan pertisipasi setiap anggota terhadap pengorganisasian kelompok. ${ }^{26}$ Kelompok identitas di luar mereka ini merupakan "negative reference group".27 Adapun konflik internal (internal conflict) adalah memberi fungsi positif terhadap kelompok identitas mengenai adanya kesalahan prilaku. Ada prilaku anggota yang dianggap menyimpang dari teks norma kelompok sehingga perlu dikoreksi oleh kelompok tersebut. Dan juga konflik internal merupakan mekanisme bertahan dari eksistensi suatu kelompok. Novri Susan dengan mengutip Wallace dan Wolt mengatakan bahwa fungsi positif konflik internal terhadap kelompok bisa berlaku tatkala konflik tidak menyertakan nilai-nilai dan prinsip dasar. Hal tersebut berelasi dengan tipe konflik yang di ciptakan Coser bahwa konflik 
M. BAHARUDDIN:Filsafat Perenial...

yang menyertakan nilai-nilai dan prinsip dasar biasanya bersifat non realistis. $^{28}$

Franz Magniz-Suseno dalam bukunya Filsafat Dari Konteks membedakan, meskipun tidak memisahkan, konflik yang bersifat "objektif-lahiriyah" dan "subyektif batiniyah". ${ }^{29}$ Konflik yang lebih bersifat "objektif lahiriyah" terjadi dalam relasinya dengan benda, kesempatan atau tindakan lahir, jadi berhubungan dengan hal-hal yang dapat menjadi isi sebuah hak (misalnya hak, milik, melakukan kegiatan mendapatkan kesempatan) konflik "subyektif batiniyah" terjadi dalam gesekan komunikasi langsung dan berakar dalam berbagai emosi yang menyertainya (misalnya jengkel, benci, tersinggung, bosan). ${ }^{30}$ Selanjutnya Franz Magniz-Suseno membedakan antara "konflik" sebagai paham yang lebih umum di satu pihak dan "konflik terbuka" dan perkelahian di lain pihak. ${ }^{31}$ Konflik, Soseno memahami sebagai situasi interaktif yang dapat menimbulkan konflik terbuka berupa tabrakan, perkelahian, atau perang. Menurut Franz Magniz-Suseno adanya konflik berarti ada perbedaan paham atau alternatif-alternatif atau kepentingankepentingan yang saling mengecualikan. Tentang jenis konflik ini Novri menjelaskan "kita mempunyai dua jenis konflik, yaitu "konflik vertikal" dan "konflik horizontal". ${ }^{2}$ Yang di maksud dengan konflik vertikal adalah konflik antara elite dan massa. Hal yang menonjol dalam konflik ini adalah di gunakannya instrumen kekerasan negara, sehingga makan korban di pihak masyarakat. ${ }^{33}$ Adapun yang di maksud dengan konflik "horizontal " ialah konflik yang terjadi di kalangan massa (rakyat) sendiri. ${ }^{34}$

Tentang tipe tipe konflik ini, Novri Susan membagi dalam tiga tipe yaitu : konflik laten, konflik terbuka dan konflik di permukaan. ${ }^{35}$

a. Konflik laten ialah suatu keadaan yang di dalamnya terdapat banyak persoalan sejatinya tersembunyi dan perlu di angkat kepermukaan agar bisa di tangani. Kehidupan masyarakat yang tampak stabil dan 
M. BAHARUDDIN:Filsafat Perenial...

harmonis belum merupakan jaminan bahwa di dalamnya masyarakat tidak terdapat permusuhan dan pertentangan.

b. Konflik terbuka adalah situasi ketika konflik sosial telah muncul kepermukaan yang berakar dalam dan sangat nyata, dan memerlukan berbagai tindakan untuk mengatasi akar penyebab dan berbagai efeknya.

c. Konflik di permukaan : memiliki akar yang dangkal atau telah berakar dan muncul hanya karena kesalahpahaman mengenai sasaran, yang dapat di atasi dengan meningkatkan komunikasi (dialog terbuka),...36

\section{Terjadinya Konflik}

Tantangan bagi perdamaian adalah konflik. ${ }^{37}$ Konflik merupakan salah satu fakta sosial bahkan proses sosial yang sering lahir dalam realitas hubungan sosial antar individu dan antar kelompok. ${ }^{38}$

Konflik biasanya lahir karena perbedaan simbol-simbol budaya yang pada tahap berikutnya memunculkan kepentingan yang tidak sealur antara satu kelompok dengan kelompok lainnya perbedaan kepentingan tersebut selanjutnya pada saat tertentu memunculkan konflik antara satu dengan yang lain. Coser memberikan apresiasi terhadap asal terjadinya konflik sosial berpendapat bahwa asal muasal konflik adalah adanya keagresipan atau bermusuhan dalam diri orang (hos tile feeling) dan dia memperhatikan bahwa dalam hubungan intim dan tertutup, antara cinta dan rasa benci hadir. ${ }^{39}$ Menurut Coser, perilaku permusuhan inilah yang menyebabkan masyarakat mengalami situasi konflik. ${ }^{40}$ Menurut Wallace dan Wolf, bahwa konflik dalam segala sejarah kontemporer adalah akibat benturan kepentingan kelompok-kelompok sosial. ${ }^{41}$

John W.Buton menegaskan bahwa konflik terjadi karena adanya pertentangan yang terus-menerus antara satu pihak dengan 
M. BAHARUDDIN:Filsafat Perenial...

pihak lain dalam hal alokasi sumber daya (resource allocation) peran dan hak. ${ }^{42}$ Dengan mengutip Watkins, Sufyan menjelaskan bahwa, konflik bisa terjadi bila terdapat dua hal a) konflik bisa terjadi bila sekurang-kurangnya terdapat dua pihak yang secara potensial dan praktis/operasional dapat saling menghambat. Secara potensial artinya, mereka memiliki kemampuan untuk menghambat. Sedang secara praktis/operasional maksudnya kemampuan tadi bisa diwujudkan dan ada dalam keadaan yang memungkinkan perwujudannya secara mudah, artinya, bila kedua belah pihak tidak dapat menghambat, maka konflik tidak akan terjadi. ${ }^{43}$ Konflik dapat terjadi bila ada suatu sasaran yang sama-sama di kejar oleh kedua pihak, namun hanya salah satu pihak yang memungkinkan untuk mencapainya. ${ }^{44}$

Dalam teori sosiologi konflik, konflik biasanya muncul dalam beberapa nuansan: konflik bernuansa agama, etnik, ekonomi, politik, budaya, dan lain sebagainya. Konflik sosial bernuansa agama dan etnik ini terjadi di beberapa wilayah Indonesia yang mempunyai falsafah Pancasila, misalnya sebagaimana dipaparkan di atas bahwa konflik sosial bernuansa agama terjadi di Banjarmasin 1997, Konflik sosial bernuansa etnik di Kalimantan Barat, konflik sosial bernuansa Agama di Poso, konflik sosial bernuansa agama di Kupang-Nusa Tenggara Timur, konflik sosial bernuansa agama di Ambon dan lain sebagainya.

\section{Resolusi Konflik}

Menurut Franz Magniz-Suseno, ada dua kemungkinan untuk resulusi konflik: secara damai atau secara paksa. ${ }^{45}$ Paksaan bisa bersifat fisik (saling memukul, berkelahi dengan atau tanpa senjata). Atau bersifat rohani. (seperti mengancam orang lain agar tidak mengemukakan pendapatnya). Atau bersifat sosial dalam berbagai dimensi (saling menekan atau memaksa untuk melakukan atau tidak) merelakan sesuatu misalnya untuk menyingkirkan prodak lawan dari pasaran dan lain-lain. Menurut Magniz, apabila konflik 
M. BAHARUDDIN:Filsafat Perenial...

beralih menjadi tabrakan perkelaian-perkelahian dan perang, berarti bahwa pihak-pihak yang bersangkutan tidak mau memecahkannya secara damai melainkan memilih jalan hendak memaksa pemecahan konflikitu.

Menurut Irfan Abu Bakar dan Chaidir S Budiman ada dua metode dalam resolusi konflik ialah metode fasilitasi dan metode mediasi. ${ }^{46}$ Metode fasilitasi dalam mengelola konflik harus ada usaha intensif untuk mencari cara-cara guna memungkinkan dialog antara pihak-pihak yang berkonflik, tanpa adanya dialog, maka kemungkinan strategi yang dipakai adalah pemaksaan dengan kekerasan. Dalam hal ini fasilitasi untuk terjadinya dialog adalah sangat berguna selama tahap konfrontasi, sebelum situasinya berkembang menjadi krisis. Fasilitasi dialog memungkinkan orang untuk membagikan pandangan mereka sendiri dan mendegarkan pandangan yang berbeda dari pihak lain mengenai isu-isu politis atau sosial. Tercapainya kesepakatan bukan merupakan tujuan utama dialog tetapi yang perlu adalah saling memahami. ${ }^{47}$

Dalam metode mediasi menurut Irfan Abu Bakar dan Chaidir S Budiman terdapat prinsip-prinsip pokok pendekatan antara lain : mediasi menuntut adanya kepedulian terhadap penderitaan dan keterlibatan seseorang dalam suatu konflik. Mediator memandu dan mengendalikan proses mediasi, tetapi harus berusaha untuk mengarahkan isi pembicaraan. Berbagai pilihan untuk menyelesaikan konflik harus datang dari kedua belah pihak sendiri yang harus merasa "memiliki" kesepakatan yang diambil. ${ }^{48}$

\section{Konflik Sosial di Indonesia}

Di muka dipaparkan bahwa telah terjadi konflik sosial di Indonesia apa itu bernuansa agama atau bernuansa etnis. Departemen Agama RI mendiskripsikan konflik-konflik tersebut misalnya konflik bernuansa agama di Banjarmasin, Konflik sosial bernuansa etnis di kalimantan barat, konflik sosial bernuansa agama di Poso, 
M. BAHARUDDIN:Filsafat Perenial...

konflik sosial bernuansa agama di Ambon, Konflik sosial bernuansa SARA di Kalimantan Tengah/Palangkaraya, konflik sosial bernuansa etnis di Kotawaringin dan lain sebagainya, sebagaimana tergambarkan secara selintas sebagai berikut:

\section{a. Konflik sosial bernuansa agama di Banjarmasin}

Tragedi konflik sosial di Banjarmasin terjadi pada hari jumat tanggal 23 Mei 1997, atau yang dikenal dengan "jumat kelabu" lebih dominan bernuansa politik. Namun demikian nuansa agama tidak dapat diketepikan begitu saja karena dipergunakannya simbol-simbol agama dalam tragedi tersebut. Selain aspek-aspek sosial dan ekonomi ikut berperan juga. ${ }^{49}$ Tragedi Banjarmasin tersebut telah memakan banyak korban manusia 320-326 orang. Selain korban meninggal ada juga korban yang hilang sebanyak 199 orang, tapi ada pula sampai saat ini tidak diketahui nasibnya, itu belum korban materi yang tidak sedikit kerugiannya.

\section{b. Konflik Sosial Bernuansa Agama di Poso}

Menurut Mursyid Ali, tragedi yang di Poso-Sulawesi Tengah ini secara umum merupakan konflik horizontal antar kelompok setempat. Sementara penyebab utamanya diprediksi adalah faktor-faktor diluar agama yakni berbagai kesenjangan di bidang ekonomi, politik, hukum, tidak efektifnya pemerintahan dan aparat keamanan. ${ }^{50}$ Tragedi Poso ini mengakibatkan tidak kurang dari 504 orang meninggal, 313 orang luka, 7022 rumah terbakar, 1.378 rusak berat, 690 rusak ringan dan masih banyak korban materi lainnya.

\section{c. Konflik Sosial bernuansa agama di Kupang Nusa Tenggara Timur}

Menurut Ibnu Hasan Muchtar, di antara pemicu tragedi Kupang adalah oleh karena ketidakpuasan masyarakat 
M. BAHARUDDIN:Filsafat Perenial...

terhadap penanganan kerusuhan di luar/Jakarta pemerintah pusat yang tidak tuntas. Kerusuhan Kupang adalah politik yang melibatkan simbol-simbol agama.51 Tragedi di Kupang Senin 30 November s/d selasa 1 Desember 1998 telah memakan korban material 5.525 miliar, dan di prediksi sekitar 4000 orang mengungsi untuk menyelamatkan diri. ${ }^{52}$

\section{d. Konflik sosial bernuansa agama di Ambon}

Kondisi sosiologis yang melatar belakangi konflik yang menjurus kerusuhan di Ambon ini adalah karena perasaan makin terdesaknya umat kristen secara politik, ekonomi, dan demografis. Konflik Ambon ini tidak mudah untuk menggambarkanya dengan terperinci kerusuhan tersebut secara singkat. konflik Ambon ini menyerupai sepiral, berputar putar dalam tahapan meningkat, pecah konflik terbuka, turun, meningkat lagi, pecah lagi, dan seterusnya. ${ }^{53}$

Selama konflik dan kerusuhan Ambon-Maluku. 1999 ada yang mengatakan telah menelan korban jiwa meninggal lebih 12.000 jiwa, 5 data yang akurat sampai sekarangbelum ada pada penulis.Di samping itu rumah penduduk hancur / terbakar. ${ }^{54} 414$ unit rumah ibadah, 251 sarana pendidikan, 129 unit dan lain -lain. ${ }^{55}$

\section{Filsafat Perennial Sebagai Alterntif Metode Resolusi Konflik Agama Di Indonesia}

Di muka di paparkan bahwa, konflik sosial yang bernuansa agama yang menjurus kepada kerusuhan dan kekerasan telah terjadi di berbagai wilayah Indonesia, seperti di Banjarmasin,di Kupang, di Poso, di Nusa Tenggara Timur, di Ambon dan lain sebagainya.Kondisi demikian menunjukan adanya dimensi subtansial agama yang belum sepenuhnya dipahami oleh sebagian besar masayarakat Indenesia adanya klaim-klaim kebenaran yang bersifat radikal telah 
M. BAHARUDDIN:Filsafat Perenial...

menyingkirkan makna subtansial agama sebagai petunjuk menuju kebahagian yang hakiki. Filsafat perennial sebagai alternatif metode resolusi konflik agama di Indonesia menawarkan beberapa metode:

Pertama, metode dialog.Metode dialog, dialog yang tidak mengandalkan kekuatan fisik, melainkan mengandalkan dan mengendalikan kemampuan intelektual. Metode yang digunakan adalah dalam dialog agama-agama biasaya adalah metode fenomenologi (fenomenologi agama), yaitu suatu cara memahami agama yang ada dengan sikap asprisiatif tanpa semangat penaklukan atau pengkafiran. Dialog agama dengan metode fenomenologi ini, yang menurut Komaruddin Hidayat dan Muhammad Wahyuni Nafis, meskipun masih terasa aspek dakwahnya-suatu upaya penobatan orang lain dari keyakinannya tapi sudah cukup positif, karena disamping akan melahirkan kompetisi dibidang intelektual juga metode ini tidak berpretensi melakukan falsifikasi terhadap keyakinan orang lain dalam rangka membenarkan agamanya sendiri. Metode ini menghindari sikap, misalnya, hanya agama "kita-lah yang paling benar" sementara agama "kamu" pasti salah.

Dengan metode ini menghindari sikap eksternal menganggap agama orang lain pasti salah dan hanya agamalah yang benar, tetapi melaui pendekatan untuk menjadi pemerhati dan pendengar sehingga dapat memahami dan menghargai keberagamaan orang lain tanpa meninggalkan keyakinan sendiri. Dengan kata lain, untuk memperkuat keyakinan terhadap kebenaran agamannya, tidak berarti harus dengan mencari kesalahan agama lain tetapi memahami pemahaman keagamaan orang lain untuk lebih memperkaya pemahaman terhadap agama yang dianutnya. ${ }^{56}$

Finomenologi agama memilahkan struktur yang berbeda dari beragaman fenomena religious yang terlepas dari keterkaitan ruang dan waktu dan keterkaitan lingkungan budaya tertentu, hingga terlihat perbedaannya dengan sejarah agama yang hanya memfokuskan diri pada penyelidikan khusus filologi dan tertarik 
M. BAHARUDDIN:Filsafat Perenial...

pada ungkapan-ungkapan kultural dari agama yang kurang memperhatikan pada nilai hakiki dari kehidupan dan pengalaman relegius. ${ }^{57}$

Metode finomenologi menggunakan perbandingan sebagai sarana interpretasi yang utama untuk memahami arti dari ekpresiekpresi relegius, seperti korban, ritus-ritus persembahan dan lainlain.Metode ini mencoba menyelidiki karakteristik yang dominan dari agama dalam konteks historis-kultural, memberi arti serta menjelaskan makna internal dari tindakan-tindakan itu.Asumsi dasar dari pendekatan ini adalah bentuk luar dari ungkapan manusia yang mempuyai pola kehidupan yang teratur, yang dapat dilukiskan kerangkanya.Metode ini mencoba menemukan struktur yang mendasari fakta sejarah dan memahami maknannya yang lebih dalam, sebagaimana dimanifestasikan melalui struktur tersebut dengan hukum-hukum dan pengertian-pengertian yang khas.Hal ini bermaksud memberikan suatu pandangan menyeluruh dari ide-ide dan motif-motif yang penting dan sangat menentukan dalam sejarah. ${ }^{58}$ Metode Finomenologi tidak hanya menghasilkan suatu diskripsi mengenai fenomena yang dipelajari, namun memberikan arti yang lebih dalam dari suatu fenomena religius.Arti yang lebih dalam ini dapat dikatakan membentuk hakekat fenomena yaitu hakikat empiris.Fenomenologi agama adalah ilmu empiris, ilmu manusia yang menggunakan hasil ilmu antropologi agama yang mempelajari fenomena relegius karena fenomenologis religius mempelajari aspeknya yang khas dari kerelegiusan. ${ }^{59}$

Namun jika dialog agama-agama berenti pada metode-metode fenomenologi semacam ini saja, hasil paling jauh adalah ditemukannya adanya suatu struktur-struktur yang sama dalam setiap agama yang ekpresikan dalam berbagai cara. Untuk itu agar dialog dan studi agama-agama mengarah kepada usaha pencarian, kemungkinan adanya apa yang disebut transcendent unity of relegions (kesatuan transenden dalam agama),dialog tersebut harus 
M. BAHARUDDIN:Filsafat Perenial...

masuk dalam berbincangan metafisika, ${ }^{60}$ sebagaimana yang dikatakan oleh Hans Kung bahwa dialog tidak hanya berhenti pada sikap ko-eksistensis melainkan juga pro-eksistensi. Artinya dialog tidak hanya mengantarkan sikap bahwa setiap agama berhak untuk ber-eksistensi secara bersama-sama, melainkan juga mengakui dan mendukung-bukan menyamakan-eksistensi semua agama. ${ }^{61}$

Dengan perspektif perennial, dialog diharapkan tidak sekedar akan berhenti ditemukannya eidos dalam istilah Class J. Bleeker, sensus numinous dalam istilah Rudolf Orto, transcendental focus dalam istilah Ninian Semart, essence of relegios dalam istilah Mercia Eliade, atau Ultimete reality dalam istilah Joachim Wach, melainkan diajak lebih jauh lagi yaitu mengalami sendiri pengalaman keberagamaan berupa penyatuan diri dengan Tuhan yang dihubungkan oleh pengetahuan sejati dan gelora cinta. ${ }^{62}$ Selanjutnya dialog tidak hanya menuntut suatu sikap inklusif melainkan juga sikap paralelisme yaitu suatu sikap yang mengakui bahwa agama merupakan jalan-jalan yang sejajar maka secara etis dialog tidak dimaksudkan untuk mencampuri urusan dan ajaran agama lain, juga tidak untuk menjadikan orang lain masuk dalam keyakinan yang dianutnya melainkan untuk memperdalam tradisi agama sendirisendiri secara kritis. ${ }^{63}$ Beberapa sikap yang harus ditunjukan dalam melakukan dialog antar umat beragama adalah: 64

Pertama, toleransi. Dialog tidak akan mungkin tercapai dengan baik apabila tidak ada sikap toleran dari masing-masing pihak yang bertikai. Pandangan apriori bahwa ajaran agama lain pasti salah, merupakan salah satu bentuk intoleransi.

Kedua, paralelisme, yaitu suatu sikap yang mengakui bahwa agama merupakan jalan-jalan yang sejajar, sehingga dialog tidak berusaha untuk mencapuri urusan dan ajaran agama lain atau untuk menjadikan orang lain masuk dalam keyakinan yang dianutnya, melainkan untuk memperdalam tradisi agama masing-masing secara kritis. 
M. BAHARUDDIN:Filsafat Perenial...

Ketiga, pluralisme, yaitu menyadari adanya kemajemukan agama serta berperan aktif membangun kebersamaan secara bersama-sama.

Ada beberapa pra-anggapan yang dikemukakan oleh Arqom yang dapat dijadikan dasar untuk melakukan dialog antar agama saat ini, yaitu bahwa pertama, dalam semua agama ada pengalaman mengenai suatu realitas transenden yang mengatasi dunia yang tidak dapat dikonseptualisasikan manusia secara utuh. Kedua, realitas itu dipahami dengan berbagai cara yang baik dalam masing-masing agama maupun dikalangan semua agama dan bahwa pengakuan terhadap pluralitas diperlukan baik untuk melindungi kebebasan beragama maupun untuk menghormati keterbatasan manusiawi. Ketiga bentuk-bentuk pluralitas agama berfungsi sebagai alat atau cara; bahwa wahyu, doktrin dan disiplin rohani dari agama-agama merupakan sarana untuk mencapai realitas yang transenden. Sehingga, perlu dihindari adanya klaim kebenaran yang menyebabkan dialog menjadi sekedar adu argumentasi mngenai kebenaran yang diyakininya.

Keempat, karena keterbatasan manusia dan sekaligus kebutuhan manusia akan komitmen terhadap suatu pengalaman particular mengenai realitas yang transenden maka pengalaman particular, meskipun terbatas akan berfungsi dalam arti sepenuhnya sebagai kriteria yang mengabsahkan pengalaman keagamaan pribadi kita sendiri. Pengakuan bahwa komitmen keagamaan yang mendalam perlu dirasakan sebagai mutlak, namun juga harus tetap menghormati komitmen mutlak yang berbeda dari orang lain.

Kelima, kritik yang diberikan atau yang didapatkan hendaknya mempuyai sifat membangun tolenran dan pertujuan untuk memahami secara kritis tentang pemahaman keagamaan.

Keenam, melalui dialog secara kritis terhadap diri sendiri harus mampu menerobos lebih jauh kedalam pengalaman particular kita sendiri mengenai realitas transenden (bila mungkin kedalam realitas TEOLOGIA, VOLUME 25, NOMOR 1, JANUARI-JUNI 2014 
M. BAHARUDDIN:Filsafat Perenial...

transenden orang lain). Perkembangan rohani timbul bukan karena mengasikan diri atau sikap eklusif melainkan karena terlibat dalam pluralisme keagamaan.

Dialog semacam ini seseorang mampu menghormati komitmen sendiri sebagai hal yang mutlak untuk dirinya sendiri dan sekaligus menghormati komitmen mutlak dari orang lain. Inilah yang oleh Seyyed Hossein Nasr disebut sebagai relatively absolud (mutlak secara relative) yaitu bahwa sekalipun bentuk keagamaan atau spiritualitas itu hanya dianggap sebagai jalan-yang karenanya relatifmenuju hakikat yang Absolud, tetapi "jalan" itu harus diyakini sebagai sesuatu yang mutlak. ${ }^{65}$

\section{Dialog-Inter-agama}

Dengan prinsip-prinsip sebagaimana yang dipaparkan di atas tidaklah terlalu sukar bagi setiap umat beragama untuk melaksanakan dan implementasi dialog tentang konsep dan pengalaman keagamaan. Tentu saja dialog yang perlu dikembangkan tidak lagi terfokus pada ajakan yang berkonotasi sebagai upaya penobatan orang lain dari keyakinannya, melainkan lebih pada berbagai pengalaman dan karenanya saling memperkaya dan mendalami pengalaman dan tradisi keagamaan masing-masing. Menurut Komaruddin Hidayat, dialog dimaksud merupakan perbincangan antara dua orang atau lebih masing-masing mempuyai pandangan yang berlainan yang tujuan utamannya adalah saling belajar anatara peserta dialog sehingga masing-masing peserta tersebut dapat saja merubah pandangannya atau tambah meningkat (pengalaman).66 Dalam dialog, setiap peserta harus mendengarkan (pengalaman) peserta yang lain secara terbuka dan penuh simpatik, dengan suatu upaya memahami posisi peserta yang lain secara tepat dilihat dari posisinya masing-masing. Kata dialog disini tidak berarti harus formal, diselenggarakan dalam ruagan, tetapi yang lebih fundamental adalah dialog melalui pergaulan sehari-hari, dialog 
M. BAHARUDDIN:Filsafat Perenial...

melalui media televisi, surat kabar, dan buku-buku yang semakin meningkat pelaksanaan dan muatannya.

Karena pilihan iman seyogyannya menuntut pertanggungjawaban rasional, maka sikap kritis dan terbuka amat signifikan disamping, sudah tentu, kesiapan mental dan moral untuk menghargai hak-hak orang lain untuk bersebrangan. Jika kebebasan berpendapat secara etis dan kritis ini dapat telaksana.Maka dialog yang sehat dan kontrukstif baru dapat dilakukan, dialog kritis tersebut tentunya tidak sekedar berlaku berhadapan dengan pemeluk agama lain, melainkan juga terlebih ketika berdialog dengan diri dan agama kita sendiri. Dialog kritis terhadap diri sendiri ini penting supaya mampu menerobos lebih jauh dalam pengalaman partikular kita sendiri mengenai realitas transeden, yang pada gilirannya ketika harus mampu juga masuk kedalam pengalaman realitas transenden yang dialami orang lain. Disamping itu, melalui dialog kritis semacam ini seseorang diharapkan memperoleh pengkayaan rohani dan intelektual sehingga lebih dewasa dan mantab dalam memeluk agamanya. Kecuali hal tersebut, sikap empati terhadap keberagaman orang lain juga perlu dikembangkanwalaupun sikap tersebut menuntut penguasaan bahasa keagamaan orang lain-agar seorang tidak mudah mengambil kesimpulan yang salah mengenai (pengalaman) agama orang lain yang kemudian kesimpulan salah itu dipaksakan untuk diakui dan dijadikan dasar penilaian. ${ }^{67}$ Menurut Komaruddin Hidayat, apa yang disebut dialog inter religius adalah dialog yang dilaksanakan secara terbuka dan penuh simpati, sehingga setiap peserta dialog masing-masing berupaya untuk saling memahami posisi peserta dialog yang lain secara tepat, dan berupaya memandangnya dari dalam posisi mereka yang dipahami.

Tujuan utama dialog adalah untuk belajar dan mendengarkan pengalaman keagamaan dari masing-masing peserta dialog bukan membandingkan dan mencari agama yang paling benar, sudah pasti 
M. BAHARUDDIN:Filsafat Perenial...

penalaran bekerja dengan membuat perbandingan, klarifikasi, distingsi, dan juga kesimpulan. ${ }^{6}$ Namun hal tersebut seyogyanya tidak perlu dijadikan targed utama.Biarkannlah setiap orang memikirkan dan menyelesaikan persoalan yang lahir untuk dirinya sendiri sesuai dengan kapasitas dan orientasi yang ada padanya. Disamping berfungsi meningkatkan rasa toleransi, sebuah dialog bisa jadi akan memuculkan pengalaman traformatif yang menjadi pandangan hidup dan wawasan teologi bagi pihak-pihak yang terlibat. $^{69}$ Komaruddin Hidayat dengan mengutip Hans Kung, berpendapat dialog tidak hanya berhenti pada sikap ko-eksistensi, melainkan juga pro-eksistensi. Sebagaimana dipaparkan terdahulu secara etis dialog tidak dimaksudkan untuk mencapuri urusan dan ajaran agama lain juga tidak untuk menyalahkan orang lain dari keyakinannya yang dianut, melainkan untuk memperdalam tradisi agama sendiri -sendiri secara lebih kritis. ${ }^{70}$

Dalam konteks ke-Indonesiaan dialog keagamaan antara pihak-pihak yang terlibat dalam konflik,dengan metode dialog sebagaimana dipaparkan di atas, adalah dalam rangka membangun masyarakat rukun-damai-adil dan makmur dan berdasarkan Pancasila. Di samping itu, mengapa dialog-dialogtersebut juga atas dasar-dasar pancasila? Karena pancasila merupakan penjelmaan dan filsafat hidup orang Indonesia dan sebagai dasar atau pendirian yang nilai kebenarannya telah di yakini dan di terima oleh bangsa Indonesia sebagai dasar atau pedoman untuk menjawab atau memecahkan masalah -masalah fundamental dalam kehidupannya sedemikian rupa sehingga filsafat sering di samakan dengan pandangan hidup. ${ }^{71}$ Disamping itu, karena Pancasila mengandung nilai-nilai dasar dan nilai-nilai fundamental. Nilai nilai dasar atau fundamental di sini yang di maksud ialah bahwa nilai-nilai tersebut di dalam rumusan sila-sila Pancasila itu merupakan nilai-nilai yang mengandung pengertian abstrak umum universal. 
M. BAHARUDDIN:Filsafat Perenial...

Adapun nilai-nilai dasar yang terkandung dalam sila-sila Pancasila adalah sebagai berikut :

1. Dalam sila Ketuhanan Yang Maha Esa terkandung nilai relegius antara lain:

a. Kepercayaan terhadap adanya Tuhan Yang Maha Esa sebagai pencipta segala sesuatu dengan sifat-sifat yang sempurna dan suci seperti Maha kuasa, Maha Pengasih, Maha Adil, Maha Bijaksana, dan sebagainya;

b. Ketakwaan terhadap Tuahn Yang Maha Esa, yakni menjalankan semua perintahNya dan menjauhi segala laranganNya.

2. Dalam Sila Kemanusiaan yang adil dan beradab terkandung nilai kemanusiaan, antara lain:

a. Pengakuan terhadap harkat dan martabat manusia dengan segala hak dan wajib asasinya.

b. Perlakuan yang adil terhadap sesama manusia, terhadap diri sendiri, alam sekitar, dan terhadap Tuhan;

c. Manusia sebagai makhluk beradab atau berbudaya yang memiliki daya cipta, rasa, karsa, dan keyakinan.

3. Dalam Sila Persatuan Indonesia terkandung nilai persatuan bangsa, antara lain:

a. Pengakuan terhadap kebhinneka tunggal ikaan suku bangsa (ethnis), agama, adat istiadat, kebudayaan;

b. Pengakuan terhadap persatuan bangsa dan wilayah Indonesia serta wajib membela dan menjunjung tingginya (patriotisme).

c. Cinta dan bangga akan bangsa dan negara Indonesia (nasionalisme). 
M. BAHARUDDIN:Filsafat Perenial...

4. Dalam Sila Kerakyatan yang dipimpin oleh hikmat kebijaksanaan dalam permusya-waratan/perwakilan terkandung nilai kerakyatan, antara lain:
a. Negara adalah untuk kepentingan seluruh rakyat;
b. Kedaulatan adalah di tangan rakyat;
c. Manusia Indonesia sebagai warga negara dan warga masyarakat mempunyai kedudukan, hak, dan kewajiban yang sama;
d. Pimpinan kerakyatan adalah hikmat kebijaksanaan yang dilandasi akal sehat;
e. Keputusan diambil berdasarkan musyawarah untuk mufakat oleh wakil-wakil rakyat.

5. Dalam Sila Keadilan Sosial bagi seluruh rakyat Indonesia terkandung nilai keadilan sosial, antara lain:

a. Perlakuan yang adil di segala bidang kehidupan terutama
di bidang politik, ekonomi, dan sosial budaya;
b. Perwujudan keadilan sosial itu meliputi seluruh rakyat
Indonesia;
c. Keseimbangan antara hak dan kewajiban;
d. Menghormati hak milik orang lain;
e. Cita-cita masyarakat adil dan makmur yang merata
f. Cinta akan kemajuan dan pembangunan. ${ }^{72}$
Dalam konteks filsafat Perennial kebenaran Pancasila tidak bertentangan agama.Sila-sila pancasila khususnya sila pertama sangat jelas menunjukan pada dimensi isoterik tentang Tuhan, bahwa ke-Esaan Tuhan adalah mutlak.Suatu keniscayaan bagi Tuhan untu bersifat Maha Esa baik Esa dalam zat, sifat, maupun 
M. BAHARUDDIN:Filsafat Perenial...

perbuatan.Konsep-konsep keesaan Tuhan merupakan dimensi yang mempertemukan keragaman agama.

Universalitas kebenaran Tuhan tidak hanya tercakup dalam agama atau kitab-kitab suci (ayat-ayat kauliyah saja), tetapi juga dalam kebenaran semesta (ayat-ayat kauniyah) yang dapat ditemukan dalam ilmu pengetahuan, seni, filsafat, termaksud di dalamnya Pancasila.

Persoalan-persoalan pluralitas agama di Indonesia ini dapat didekati dengan dua pendekata.Pertama,melalui jalur pendidikan tertutama pendidikan yang terkait dengan pembentukan kepribadian, lebih khusus lagi pendidikan agama.Kedua, upaya dibukanya kembali dialog antar umat beragama.

Pendidikan agama harus diberikan secara komprehensif.Pada tingkat dasar dan lanjutan harus diberikan pelajaran agama yang berisi konsep-konsep dasar berserta dengan hal yang bersifat praktis-aplikatif, sesuai dengan agamanya masing-masing.Setiap insitusi pendidikan yang membuka kelas umum mempuyai kosekuensi untuk mengadakan pelajaran agama sesuai dengan agama subjek didiknya.Namun demikian subjek didik harus selalu diajarkan tentang kenyataan bahwa diluar dirinya ada sementara orang yang mempuyai keyakinan yang berbeda dengan keyakinannya, dan sebagai manusia mereka layak untuk dihormati. Apabila sikap dasar demikian sudah tumbuh pada setiap subjek didik sebagai insan yang terpelajar, maka kehidupan harmonis antar pemeluk agama akan lebih mudah dicapai.

Pada tingkat perguruan tinggi, Arqom dengan mengutip istilah Amin Abdullah, pendidikan agama selain mengajarkan agama sendiri (doktriner normative), mahasiswa diajak pula untuk berfikir kritis mempelajari agama dalam konteks sejara (historis kritis).Mahasiswa harus dipahamkan bahwa pluralitas merupakan kenyataan sejarah, dan bahwa setiap agama merupakan rangkaian sistemik menuju 
M. BAHARUDDIN:Filsafat Perenial...

pada kebenaran Tuhan Yang Satu. Sikap pluralis ini dapat menumbuhkan sikap toleransi serta kerja sama umat beragama. ${ }^{73}$

Kedua, Komitmen Keniscayaan Adanya Pluralitas Dalam Agama

Agama sebagaimana budaya merupakan suatu kemungkinan eksistensial yang dapat ditawarkan kepada setiap orang, sehingga pluralisme agama merupakan tantangan khusus yang dihadapi agama-gama dewasa ini.Dalam sejarah dapat dilihat bahwa agamaagama besar muncul dari komunitas agama yang plural dan membentuk diri sebagai tanggapan atas pluralitas tersebut.Agama Islam lahir ditengah-tengah pluralitas agama Nasrani, Zoroaster, pengikut Manikhea, Yahudi, dan para penyembah berhala.Pencerahan Budha muncul dalam kekacuan balauan pluralitas pandangan Brahmanis, Jaina, meterialisme, dan dokmatisme. ${ }^{74}$

Kondisi yang plural demikian tidak jarang menimbulkan kebingungan teologis sehingga banyak orang mengambil jalan "acuh tak acuh" atau bahkan lari dari agama, atau sebaliknya melakukan singkritisme terhadap ajaran-ajaran agama dengan cara mengambil sisi terbaik dari agama dan melakukan generalisasi terhadap ajaran agama tersebut sehingga muncul istilah "agama baru” yaitu - "agama thabiat", yaitu agama yang disesuaikan dengan kemauan manusia dan kemauan alam. Beberapa contoh bentuk singkritisme antara lain agama Manichaeisme yang menggabungkan unsur ajaran Zoroaster, Budha dan Kristen unsur ajaran Zoroaster Budha dan Kristen; New Age Relegion (Agama Masa kini), yang memadukan praktik yoga Hindu, meditasi Budha, Tasawuf Islam dan mistik Kristen; ada lagi agama baru yang didirikan di Iran oleh Mirzan Husain Ali Nuri yang dikenal sebagai Bahaisme, suatu perpaduan ajaran agama Yahudi Kristen dan Islam. ${ }^{75}$

Pluralisme dalam konteks beragama adalah adanya mengakui adanya keberagamaan agama ada ditengah-tengah kita. Sebab pluralism adalah fakta atau realitas yang tidak bisa dipungkiri, akan 
M. BAHARUDDIN:Filsafat Perenial...

tetapi menurut Alwi Shihab ada beberapa prinsip dasar tentang pluralism yang perlu diperhatikan:

Pertama, pluralisme tidak semata menujuk pada kenyataan tentang adanya kemajemukan, tetapi mengandung pengertian "keterlibatan aktif" terhadap kenyataan kemajemukan tersebut.76 Arqom juga mengatakan bahwa pluralitas tidak sama dengan kemajemukan. Pluralitas mengacu pada adanya hubungan saling tergantung antara berbagai hal yang berbeda, sedangkan kemajemukan (diversitas) mengacu pada tidak adanya hubungan dari hal yang berbeda tersebut.Kedua, pluralisma harus dibedakan dengan cosmopolitanisme.Cosmopolitanisme menunjuk kepada suatu realitas yang aneka ragam agama, ras, bangsa, yang hidup berdampingan disuatu lokasi.Ketiga, konsep pluralisme tidak sama dengan relativisme. Relativisme berasumsi bahwa kebenaran atau nilai ditentukan oleh pandangan hidup serta kerangka berfikir seseorang atau masyarakat, sehingga aliran ini tidak mengenal kebenaran universal.Keempat, pluralism bukanlah singkritisme, yakni menggabung-gabungkan berbagai ajaran dengan mengambil sisi-sisi tertentu sehingga muncul menjadi agama baru. ${ }^{77}$

Menurut Ahmad Mutaqqin, dari sejarahnya di Barat, Pluralisme Agama lahir sebagai sebuah reaksi atas eklusivisme Khatolik yang menurut John Hick menjadi sebab utama konflik antar umat beragama ketika itu. Karena dianggap, fanatisme agama adalah sebab timbulnya konflik, maka tercetuslah ide bagaimana agar seluruh umat beragama, khususnya Khatolik dan Kristen, dapat lebih menghormati dan menghargai agama lain yang tidak sejalan. Tujuannya sungguh mulia, yakni demi terciptanya sebuah kerukunan antar umat beragama paham inipun semakin digencarkan persebarannya, terlebih ketika realita berbicara tentang rentannya praktek kekerasan atas nama agama. Yang kalau dulu hanya dimonopoli oleh Gereja dengan inkuisisinya, maka dewasa ini praktik kekerasan atas nama agama lebih sering dituduhkan kepada 
M. BAHARUDDIN:Filsafat Perenial...

umat Islam. Baik itu dengan tuduhan teroris, fundamentalis, maupun ekstrimis. ${ }^{78}$

Filsafat perennial dalam memandang pluralitas agama ini mencari titik temu (common platform), (Common Vision) ${ }^{79}$ dalam menyelusuri matarantai historisitas tentang pertumbuhan agama, mencari esensi esoteric dalam pluralitas eksoteri pada masingmasing agama yang ada.Filsafat perennial memandang bahwa setiap agama memiliki suatu bentuk dan suatu subtansi.Subtansi mempuyai hak-hak tidak terbatas oleh karenanya lahir dari Yang Mutlak.Kemutlakan suatu agama terdapat pada subtansinya dan bersifat intrinsip. Ketika suatu agama beradapan dengan agama yang nampak adalah realitas bentuk dan secara ekstrinsik menjadi relative, suatu agama hanya merupakan satu bagian dari sekian agama yang ada. Maka ketika setiap agama menyatakan dirinnya adalah mutlak saat itu pulah muncul kemutlakan yang oleh Nasr dikatakan relatively absolud atau absolutely relative. ${ }^{80}$

Dalam konteks ini setiap penganut agama harus menyadari bahwa kemutlakan agama yang mereka yakini adalah relatif apabila dihadapkan pada "pluralitas kemutlakan, agama lain, setiap pemganut agama mempuyai hak yang sama untuk menganggap bahwa agamanya paling benar menurut keyakinannya. Ketika pemahaman ini muncul maka harus ada toleransi dan sikap menghargai di antara berbagai keyakinan tersebut.

Filsafat perennial berpandangan bahwa kebenaran Mutlak (the Truth) hanyalah satu. Dari Yang satu itu memancar berbagai kebenaran, sebagaiman cahaya matahari akan tampak berwarna hijau ketika ditangkap oleh daun dan berwarna merah ketika ditangkap oleh bunga mawar, demikian pula dengan agama. ${ }^{81}$ Agama juga mengandung pengertian Agama (dengan " $A$ " besar) dan agama (dengan "a" kecil). Merupakan realitas kongkrit sebagai pancaran dari agama (dengan"A" besar). Klaim kebenaran (truth claim) yang tampak dalam realitas keberagamaan saat ini, banyak yang terjebak 


\section{BAHARUDDIN:Filsafat Perenial...}

pada klaim kebenaran pada tingkat "agama” .(dengan "a" kecil) Mereka memutlakan "agama"padahal Itu relative, dan mengesampingkan sisi ke-Agamaan-Nya dan mengklaim agama lain adalah salah dan harus ditentang. ${ }^{82}$ Pembantaian, perselisihan, konflik agama di Indonesia seperti peristiwa di Ambon, Banjarmasin, Poso, dan lain sebagainya menunjukkan bahwa tidak adanya pemahaman keagamaan yang benar. Banyak orang merasa mengabdi dan berjuang kepada Tuhan padahal mereka hanya mengabdi kepada "agama".

Esoterisme dan eksoterisme adalah dualitas integral dalam agama sebagaiman dua sisi mata uang yang tidak dapat dipisahkan satu dengan yang lain. Esoterisme meskipun secara substansial adalah universal, pluralitas eksoterisme agama akan terlihat sangat beragam sebagai pengungkapan makna esoterik yang dipahami masing-masing agama. ${ }^{83}$

Adanya klaim kebenaran pada dataran eksoterisme selama bersifat internal adalah benar dan justru sangat diperlukan, karena bagaimana mungkin melaksanakan ajaran agama tanpa ada keyakinan bahwa ajaran itu benar. Hanya yang menjadi persoalan adalah ketika klaim itu bersifat eksternal sehingga menepatkan agama lain pada posisi lawan. Untuk menjauhkan terjadinya konflik antar penganut agama, maka dialog antar umat beragama menjadi sangat penting untuk membangun komitmen keniscayaan adanya pluralitas agama dan menjalin hubungan yang harmonis antar pemeluk agama.

Konsep Islam dalam membangun komitmen keniscayaan adanya pluralitas agama tampak jelas dalam berbagai ayat al-Quran, sebagai berikut

Wahai seluruh manusia, sesungguhnya Kami telah menciptakan kamu (berasal) dari seorang laki-laki dan seorang perempuan, dan Kami jadikan kamu berbangsa-bangsa dan bersuku-suku agar kamu saling kenal mengenal (bantu-membantu).Sesungguh- 
M. BAHARUDDIN:Filsafat Perenial...

nya yang paling mulia diantara kamu disisi Allah adalah yang paling bertaqwa. Sesungguhnya Allah Maha Mengetahui lagi Maha Mengenal (QS.al-Ḥujurāt [49]: 13).

Untuk tiap-tiap umat diantara kamu, Kami berikan aturan dan jalan terang.Sekiranya Allah menghendaki, niscaya kamu dijadikan-Nya satu umat saja, tetapi Allah hendak menguji kamu terhadap pemberitaan-Nya kepadamu. Maka berlomba-lombahlah dalam kebaikan (QS.al Mā'idah [5]:48).

Dari ayat di atas menunjukkandasar-dasar komitmen keniscayaan adanya pluralitas yaitu: pertama, secara genetis semua manusia dengan beragam bangsa dan warna kulit adalah berasal dari rahim yang sama. Kata "rahim" dalam hal ini perlu diberi makna lebih luas, yaitu "rahim" dalam arti fisiologi, bahwa semua manusia berasal dari kandungan ibu yang sama Siti Hawa, makna yang lain adalah pengertian "rahim" yang berasal dari bahasa Arab yang berarti "kasih sayang" kesadaran manusia akan konsep rahim ini dapat memberi implikasi pada perlunya dibangun konsep kasih sayang plural antar umat manusia. Kedua, Tuhan telah meniscayakan adanya perbedaan-perbedaan di kalangan umat manusia. Perbedaan tidak dipahami sebagai perpecahan dan perselisihan, tetapi justru berisi penyadaran akan keterbatasan dan ketergantungan manusia dengan manusia lain, sehingga memunculkan motivasi untuk tolong-menolong dan berlomba dalam berbuat kebajikan. Ayat-ayat lainnya, antara lain:

Kalau mereka itu benar-benar menegakkan ajaran Taurat dan Injil, serta yang diturunkan kepada mereka dari Tuhan mereka, pastilah mereka akan makan (mendapat rezeki, mengalami kemakmuran) dari atas mereka (langit) dan dari bawa kaki mereka (bumi). Dari mereka ada umat yang menempuh jalan kebenaran dan banyak dari mereka yang tidak baik tingkah lakuhnya (QS.al-Mā'idah [5]:66).

Dan sekiranya Ahli al-Kitab beriman dan bertakwa, tentulah Kami ampuni kesalahan-kesalahan mereka dan tentulah Kami 
M. BAHARUDDIN:Filsafat Perenial...

masukan kedalam surga-surga yang penuh kenikmatan $(\mathrm{QS}$ alMā'idah [5]: 65).

Sesungguhnya orang-orang mukmin, orang-oranng yahudi, orang-orang Nasrani dan orang șābiīn, siapa saja di anntara mereka yang benar-benar beriman kepada Allah, hari kemudian dan beramal shaleh, mereka akan menerima pahala dari Tuhan mereka, tidak ada kehawatiran terhadap mereka dan tidak pula mereka bersedih hati" (QS.al-Baqarah [2]:62).

Konsep inklusiflslam yang dideskripsikan dalam tigaayatdi atas menujukkan bahwa jalan keselamatan dalam agama terletak pada subtansinya, bukan semata-mata pada bentunya yaitu bahwa meskipun seseorang menganut agama diluar Islam, tetapi mereka secara konsekuen dan konsiten melaksanakan ajara agama tersebut, melakukan amal kebajikan serta tidak menyekutukan Allah,bagi mereka dan diberikan keselamatan dan kebahagiaan surga. Ayat ini sekaligus menujukan kasih sayang Allah yang melebihi kemurkaanNya.

Islam megajak kaum Ahli Kitab menuju kepada "pokok-pokok kesamaan" (kalimatun sawā) yaitu menuju pada ajaran tauhid (mengesakan Tuhan), ajaran yang menyatukan keragaman eksoterik agama-agama sebagaimana dideskripsikan dalamal-Quran sebagai berikut:

Katakanlah olehmu (Muhammad): "Hai Ahli Kitab, marilah menujukalimat kesamaan antara kami dan kamu, yaitu bahwa kita (semua) tidak akan menyembah kecuali Allah, dan kita tidak mepersekutukan-Nya kepada apapun juga dan sebagian dari kita tidak menjadikan sebagian yang lain sebagai Tuhan-tuhan selain Allah. Jika mereka berpaling maka katakanlah kepada mereka "saksikanlah, bahwa kami adalah orang-orang yang berserah diri (kepada Allah)" (QS. Ali Imrān [3]: 64).

Konsep pluralisme Islam ini sangat menarik Cryril Glasse : penulis "Concise Encyclopedia of islam) dengan mengatakan : ...tha fact that one revelation should name others as authentic is an 
M. BAHARUDDIN:Filsafat Perenial...

extroardinsy event in the historyof religion all"... (kenyataan bahwa sebuah wahyu (islam) menyebut wahyu-wahyu yang lain sebagai absah adalah kejadian luar biasa dalam sejarah agama-agama).

\section{Penutup}

Filsafat Perenial dapat dijadikansebagai alterntif metode resolusi konflik agama di Indonesia. Dalam hal ini filsafat perennial menawarkan dua pendekatan, yaitu: metode dialog dan komitmen keniscayaan akan adanya pluralitas dalam agama.

\section{Metode dialog}

Dialog agama sangat penting, untuk menjauhkan dari terjadinya konflik, suatu metode dialog untuk menjembatani adanya klaim kebenaran yamg biasa muncul dikalangaan pemeluk agama. Dalam hal ini, filsafat perennial menawarkan metode fenomenologi (fenomenologi agama), yaitu suatu cara memahami agama yang ada dengan sikap apresiatif tanpa semangat penaklukan dan pengkafiran. Metode ini menghindri sikap eksternal menganggap agama orang lain pasti salah dan hanya agamanya lah yang benar, tetapi melaui pendekatan untuk menjadi pemerhati dan pendengar sehingga dapat memahami dan menghargai keberagamaan orang lain tanpa meninggalkan keimanan sendiri. Untuk memperkuat keimanan tidak harus dengan mencari kesalahan agama lain tetapi memahami pemahaman keagamaan orang lain untuk lebih memperkaya pemahaman terhadap agama yang di anutnya. Dialog tidak hanya menuntut suatu sikap inklusif melainkan juga sikap paralelisme, yaitu suatu sikap yang mengakui bahwa agama merupakan jalan-jalan yang sejajar. Maka secara etik dialog tidak dimaksudkan untuk mencapuri urusan dan ajaran agama lain, juga tidak untuk menjadikan orang lain masuk dalam keyakinan yang dianutnya melainkan untuk memperdalam tradisi agama sendirisendiri secara kritis. 
M. BAHARUDDIN:Filsafat Perenial...

\section{Komitmen keniscayaan adanya pluralitas dalam agama}

Pluralitas agama merupakan suatu realitas yang terjadi saat ini, dan dalam sejarah pluralitas dapat dilihat bahwa agama-agama besar muncul dari lingkungan agama yang plural dan membentuk diri sebagai tanggapan-tanggapan plural tersebut.Dalam melihat pluralitas agama ini filsafat perennial berusaha mencari titik temuk (Common Platfom) (Common Vision) dalam menelusuri matarantai historisitas tentang pertumbuhan agama, mencari esensi esoteris dari pluralitas eksoteris pada masing-masing pada agama yang ada. Filsafat perennial dalam melihat pluralism agama meyakini bahwa setiap agama berasal dari sumber yang sama yaitu dari Yang Mutlak, kebenaran berasal dari Yang Satu.

\section{Catatan Akhir}

${ }^{1}$ Titik Suwaryati, "Konflik-konflik Sosial Bernuansa Agama di Berbagai Komunitas: Kasus Kerusuhan Sosial di Banjarmasin 1997", dalam Konflik Sosial Bernuansa Agama di Indonesia, Jakarta: Departemen Agama RI, 2003,h.1.

2Umar Surur, "Konflik Sosial Bernuansa SARABerbagai Komunitas Etnik di Kalimantan Barat", dalam Konflik Sosial Bernuansa Agama di Indonesia, Jakarta: Departemen Agama RI, 2003, h.25.

${ }^{3}$ Mansur Hidayat, "Budaya Lokal Dalam Pencegahan dan Penyelesaian Konflik",Bina al-Ummah: Jurnal Ilmu Dakwah dan Pengembangan Komunitas, Vol. IV, 2011, h. 206.

${ }^{4}$ Ibid,h.207.

5Hasan Shadily, Ensiklopedi Indonesia, Jli. IV, Jakarta:Ikhtisar Baru VAN HOEVE, 1983, h. 1849.

${ }^{6}$ W.J.S. Poerwadarminta,Kamus Umum Bahasa Indonesia,Jakarta: Balai Pustaka,1976; Novri Susan, Sosiologi Konflik, Jakarta: Kencana, 2009, .h. 4.

7Diana Francis, Teori Dasar Transformasi Konflik Sosial, Yogyakarta: Qualls,2006,h.7. 
${ }^{8}$ Novri Susan, Sosiologi Konflik,h. 5.

9Ibid.

10Ibid.

11Ibid.

12Willian Kornblorn, Sociologi in the Changing World, USA:Wardsmoth Thompson Learning, 2003,h. 290.

${ }^{13}$ Novri Susan, Sosiologi Konflik, h..2.

${ }^{14}$ Ibid.

15Ibid.

16 Ibid.

${ }^{17}$ Simon Fisher, Mngelola Konflik Keterampilan Strategi untuk Bertindak, Jakarta: Grafika Pertama,2001,h.4.

18Ibid.

19Ibid.

20Ibid.

${ }^{21}$ Titik Suwaryati, Konflik Sosial, h. .5.

${ }^{22}$ Mansur Hidayat, Budaya Lokal,h.205.

${ }^{23}$ Ibid.

${ }^{24}$ Ibid.

${ }^{25}$ Novri Susan, Sosiologi Konflik, h.55.

26Ibid.

27Ibid.

28Ibid.

${ }^{29}$ Franz Magniz-Suseno, Berfilsafat Dari Konteks, Jakarta: Gramedia,1992,h.201.

30Ibid.

31Ibid.,h.203.

${ }^{32}$ Novri Susan, Sosiologi Konflik, h.93.

33Ibid.

34Ibid.

35Ibid.,h.93.

36Franz Magniz-Suseno,Berfilsafat,h.204.

37Mansur Hidayat, Budaya Lokal, h.204.

${ }^{38}$ Lewis Coser, "Social Conflict and the Theory of Social Change,"British Journal of Sociology, 8:3 September 1957,h. 197.

${ }^{39}$ Novri Susan, Sosiologi Konflik, h. 54.

${ }^{40}$ Wallace dan Wolf, Reading in contemporary sociological theory from modernity to post. Modernity, New Jorsey, prentice jall, hal.79 
${ }^{41}$ John W Burton, Controlled communication to analytical problem solving :dalam Rosaed J.Fisher, Interactive Conflict Solution, London: Syracuss Press, h.15.

${ }^{42}$ Sofyan M.Sholeh, Analisis Empiris Konflik Eksekutif dan Legislatifdi Provinsi Lampung 2002-2009, Yogyakarta: Pustaka Utama 2010, h.15.

43Ibid.

44Franz Magniz-Suseno, Berfilsafat, h. 203.

45Irfan Abu Bakar dan Chaidir S Bamualim, Resolusi Konflik Agama dan Etnis di Indonesia, Jakarta: UIN Syarif Hidayatullah,2006,h.129.

46Ibid.,h.139.

${ }^{47}$ Titik Suwaryati, Konflik Sosial, h.22.

${ }^{48}$ Ibid.,h.15.

${ }^{49}$ Umar Surur, Konflik Sosial, h.30.

50Ibid.,h.71.

${ }^{51}$ Mursyid Ali,"Konflik Sosial Bernuansa Agama: Studi Kasus tentang TragediKerusuhan Poso",dalamKonflik Sosial Bernuansa Agama di Indonesia, Jakarta, Departement Agama RI,2003,h.82-83.

52Ibid.,h. 91-92.

${ }^{53}$ Syuhada Abduh,"Tragedi Berdarah di Kotawaringin Timur: Kasus Dayak dan Madura tahun 1999",dalamKonflik Sosial Bernuansa Agama di Indonesia, Jakarta: Departemen Agama RI, 2003, h. 231.

54Ibid.,h.258.

55Sudjangi, "Konflik-konflik Sosial Bernuansa Agama:Studi Kasus Kerusuhan Ambon",dalamKonflik Sosial Bernuansa Agama di Indonesia, Jakarta: Departemen Agama RI,2007,h.178.

${ }^{56}$ Arqom Kuswanjono, Ketuhanan dalam Telaah Filsafat Perenial Refleksi Pluralisme di Indonesia, Yogyakarta: Filsafat UGM, 2006, h. 96.

57Mariasusai Dhavamony, Pluralisme: Tantangan dari Agamaagama, Yogyakarta: Kanisius, 1995, h. 31.

${ }^{58}$ Arqom Kuswanjono, Filsafat Perennial, h. 105.

${ }^{59}$ Ibid.

${ }^{60}$ Komaruddin Hidayat dan Muhammad Wahyuni Nafis, Agama Masa Depan Perspektif Filsafat Perenial,Jakarta: Paramadina, 1995, h. 75.

${ }^{61}$ Arqom Kuswanjono, Filsafat Perenial dan Rekontruksi Pemahaman Keberagamaan, Yogyakarta: Filsafat UGM, 2006, h. 105106 
M. BAHARUDDIN:Filsafat Perenial...

${ }^{62}$ Komaruddin Hidayat dan Muhammad Wahyuni Nafis, Agama, h. 75.

63Raimundo Panikker, Dialog Intra Relegius, Yogyakarta: Kanisius, 1984, h. 22-23.

${ }^{64}$ Arqom Kuswanjono, Ketuhanan, h. 97.

65Ibid.

66Komaruddin Hidayat dan Muhammadd Wahyuni Nafis, Agama,h. 80.

67Ibid.

68Ibid.

69Ibid.

70 Ibid.

${ }^{71}$ Franz Magniz-Suseno, Berfilsafat,h.23.

${ }^{72}$ Soejadi, Pancasila Sebagai Sumber Topik Hukum Indonesia, Yogyakarta: Lukman Offset, 1999,h.88-90.

${ }^{73}$ Arqom Kuswanjono, Ketuhanan, h.96.

${ }^{74}$ Ibid.; lihat Harold Coward, Pluralisme: Tantangan bagi Agamaagama, terj. Bosco Carvalo, Yogyakarta: Kanisius, 1989, h. 168.

${ }^{75}$ Jainala Aripin Abbas,Pekembangan Pemikiran terhadap Agama, Jakarta: Pustaka Al-Husna, 1984, h.73.

${ }^{76}$ Alwi Shihab, Islam Inklusif, Menuju Sikap Terbuka dalam Beragama, Bandung: Mizan, 1998, h. 41-42.

${ }^{77}$ Arqom Kuswanjono, Ketuhanan, h. 86.

${ }^{78}$ Ahmad Muttaqin, "Rekonstruksi Gagasan Pluralisme Agama:Telaah atas Buku Pluralisme Agama, musuh agama-agama karya Adian Husaini", Jurnal al-Adyan: Jurnal Lintas Studi Agama, Vol. IX, No. 1, Januari-Juni 2014, Jurusan Perbandinagan Agama, FU IAIN Raden Intan Lampung, 2014, h. 97.

${ }^{79}$ Arqom Kuswanjono, Aktualisasi, h. 101.

${ }^{80}$ Komaruddin Hidayat dan Muhammad Wahyuni Nafis, Agama, h. 13.

${ }^{81}$ Arqom Kuswanjono, Aktualisasi, h.101.

${ }^{82}$ Komaruddin Hidayat dan Muhammad Wahyuni Nafis, Agama, h.XX.

${ }^{83}$ Arqom, Aktualisasi, h.101-102. 


\section{DAFTAR PUSTAKA}

Abduh, Syuhada, "Tragedi Berdarah di Kotawaringin Timur: Kasus Dayak dan Madura tahun 1999", dalam Dalam Konflik Sosial Bernuansa Agama di Indonesia, Jakarta: Departement Agama RI,2003.

Ali, Mursyid, "Konflik Sosial Bernuansa Agama: Studi Kasus tentang TragediKerusuhanPoso", dalam Dalam Konflik Sosial Bernuansa Agama di Indonesia, Jakarta: Departement Agama RI,2003.

Aripin, Jainala Abbas, Pekembangan Pemikiran Terhadap Agama, Jakarta: Pustaka Al-Husna, 1984.

Bamualim, Chaidir S, dan Irfan Abu Bakar, Resolusi Konflik Agama dan Etnis di Indonesia, Jakarta,UIN Syarif Hidayatullah,2006.

Coser, Lowis, "Social Conflict and the Theory of Social Change", British Journal of Sociology, 8:3 September 1957.

Dhavamony, Mariasusai, Pluralisme: Tantangan dari Agama-agama, Yogyakarta: Kanisius, 1995.

Fisher,Simon, Mengelola Konflik Keterampilan Strategi Untuk Bertindak, Jakarta:Grafika Pertama,2001.

Francis, Diana, Teori Dasar Transformasi Konflik Sosial, Yogyakarta: Qualls,2006.

Hasan, Ibnu Mukhtar, "Konflik-konflik Sosial Bernuansa Agama: Studi Kasus Kerusuhan Kupang Nusa Tenggara Timur 30 November 1998" dalamKonflik Sosial Bernuansa Agama di Indonesia, Jakarta: Department Agama RI, 2003.

Hidayat, Mansur, "Budaya Lokal dalam Pencegahan dan Penyelesaian Konflik", Bina al-Ummah: Jurnal Ilmu Dakwah dan Pengembangan Komunitas, Volume IV, 2011.

Kornblorn, Willian,Sociology in the Changing World, USA:Wardsmoth Thompson Learning, 2003.

Kuswanjono, Arqom, Filsafat Perenial dan Rekontruksi Pemahaman Keberagamaan, Yogyakarta: Filsafat UGM, 2006.

TEOLOGIA, VOLUME 25, NOMOR 1, JANUARI-JUNI 2014 
Kuswanjono, Arqom, Ketuhanan dalam Telaah Filsafat Perenial Refleksi Pluralisme di Indonesia, Yogyakarta: Filsafat UGM, 2006.

Magniz-Suseno, Franz, Berfilsafat dari Konteks, Jakarta: Gramedia,1992.

Nafis, Muhammad Wahyuni, dan Komaruddin Hidayat, Agama Masa Depan Perspektif Filsafat Perenial, Jakarta: Paramadina, 1995.

Panikker, Raimundo,Dialog Intra Relegius, Yogyakarta: Kanisius, 1984

Poerwadarminta, W.J.S, Kamus Umum Bahasa Indonesia, Jakarta: Balai Pustaka,1976.

Shadily, Hasan, Ensiklopedi Indonesia, Jil. IV, Jakarta: Ikhtisar Baru VAN HOEVE, 1983.

Shihab, Alwi,Islam Inklusif, Menuju Sikap Terbuka dalam Beragama, Bandung: Mizan, 1998.

Soejadi, Pancasila Sebagai Sumber Topik Hukum Indonesia, Yogyakarta: Lukman Offset, 1999.

Sofyan, M.Sholeh, Analisis Empiris Konflik Eksekutif dan Legislatifdi Provinsi Lampung,2002-2009,Yogyakarta: Pustaka Utama, 2010.

Sudjangi, "Konflik-Konflik Sosial Bernuansa Agama Studi Kasus Kerusuhan Ambon", dalam Konflik Sosial Bernuansa Agama Di Indonesia, Jakarta, Departemen Agama RI,2007.

Surur,Umar, "Konflik Sosial Bernuansa SARABerbagai Komunitas Etnik di Kalimantan Barat", dalam Konflik Sosial Bernuansa Agama di Indonesia, Jakarta: Departement Agama RI, 2003.

Susan, Novri, Sosiologi Konflik, Jakarta: Kencana, 2009.

Susan, Novri,Sosiologi Konflik: Isu-isu Konflik Kontemporer, Jakarta: Kencana,2009.

Suwaryati,Titik, "Konflik-konflik Sosial Bernuansa Agama di Berbagai Komunitas: Kasus Kerusuhan Sosial di Banjarmasin, 1997", dalam Konflik Sosial Bernuansa Agama di Indonesia, Jakarta: Departemen Agama RI, 2003. 